\title{
Anti-proliferative Activity of Crotalaria pallida Aiton on MCF-7 Breast Cancer Cells
}

Erladys M. Rumondor, Moelyono Moektiwardoyo, Melisa I. Barliana

\begin{abstract}
Department of Biology Pharmacy, Faculty of Pharmacy, Universitas Padjadjaran, Jatinangor, West Java, Indonesia
\end{abstract}

\begin{abstract}
Crotalaria pallida Aiton (C. pallida Aiton) is empirically used as dietary supplement to treat cancer by the people of North Sulawesi. However, its scientific pharmacology activity has not been explored yet. Therefore, this study was conducted to evaluate anti-proliferative activity of $C$. pallida Aiton on MCF-7 breast cancer cells. The extraction of leaves and seeds were performed using ethanol, ethyl acetate, n-hexane, and water. Phytochemical screening was then performed to identify secondary metabolites in this extract. Anti-proliferative activity was evaluated using 3-(4,5-dimethylthiazol-2-yl)-2,5-diphenyltetrazolium bromide (MTT) assay. The results indicated that ethyl acetate fraction of $C$. pallida Aiton has the lowest $\mathrm{IC}_{50}(29,67)$. In conclusion, ethyl acetate fraction of $C$. pallida Aiton is potential to be developed as anti cancer agent.
\end{abstract}

Keywords: Crotalaria pallida Aiton, WST assay, MCF-7 cell line

\section{Introduction}

Breast cancer is the most common lifethreatening cancer in women and the leading cause of cancer death among women. Cancer cells are very similar to cells of the organism from which they originated and have similar (but not identical) DNA and RNA. ${ }^{1-3}$

The toxicity of chemotherapeutic drugs sometimes creates a significant problem in the treatment of cancer using allopathy or established medicine. Various therapies have been propounded for the treatment of cancer, many of which use plant-derived products. ${ }^{4-6}$
Crotalaria pallida Aiton (C. pallida Aiton, Leguminoceae family, was empirically used by the people of North Sulawesi to treat cancer. However, its scientific pharmacology activity has not been explored yet.

Therefore, this study was conducted to evaluate anti-proliferative activity of Crotalaria pallida Aiton on MCF-7 breast cancer cells. Such information is essential to provide evidence on the anti-cancer activity of this medicinal plant from Indonesia. 
Table 1. Result of phytochemical screening

\begin{tabular}{|c|c|c|c|c|c|c|c|c|}
\hline \multirow{3}{*}{ Compound } & \multicolumn{8}{|c|}{ Sample } \\
\hline & \multicolumn{3}{|c|}{ Seeds Fraction } & \multicolumn{3}{|c|}{ Leaves Fraction } & \multirow{2}{*}{$\begin{array}{c}\text { Seed } \\
\text { Extract }\end{array}$} & \multirow{2}{*}{$\begin{array}{l}\text { Leaves } \\
\text { Extract }\end{array}$} \\
\hline & $\mathbf{n}-\mathbf{h}$ & ea & water & n-h & ea & water & & \\
\hline Alkaloid & - & + & + & + & + & + & + & + \\
\hline Flavonoid & - & + & - & - & - & + & + & - \\
\hline Saponin & + & + & + & + & + & + & + & + \\
\hline Triterpenoide & + & + & - & + & + & - & + & - \\
\hline Steroid & + & + & - & + & + & - & + & - \\
\hline Fenol & - & + & + & - & + & + & - & + \\
\hline Monoterpene & - & + & + & - & + & + & + & + \\
\hline Sesquiterpene & - & + & + & - & + & + & + & - \\
\hline
\end{tabular}

n-h: n-hexane; ea: ethyl acetate.

\section{Methods}

The plant materials used in this study were $1195.45 \mathrm{~g}$ and $2449.93 \mathrm{~g}$ of C. pallida Aiton leaves and seeds, respectively. The solvents used were ethyl acetate, n-hexane, distilled water, fetal bovine serum (FBS) (Gibco), phosphate buffer saline (PBS), water soluble tetrazolium (WST-8) (Dojindo) kit, and sodium dodecyl sulphate (SDS). The cell line used was MCF-7 breast cancer cells (Cell Culture Laboratory of Universitas Padjadjaran).

Cold extraction of leaves and seed of $C$. pallida Aiton was performed using ethanol. for $3 \times 24$ hours. These extracts were then fractionated using several solvents with different polarity.

Phytochemical screening was performed with several reagents to identify the presence of secondary metabolites such as alkaloid (Mayer-Dragendorff), flavonoid, polyphenol, quinone, tannin, monoterpenoid, sesquiterpenoid, and saponin.

\section{Alkaloid Compound}

The extract was moistened by adding a small amount of ammonia. Chloroform. was then added to the solution. The chloroform layer is then removed while being filtered.. Subsequently, hydrochloric acid was added. The mixture was shaken firmly to form several layers. The second layer was added by Mayer's reagent. The presence of white sediment indicated the presence of alkaloid group compounds. The third layer was then added with Dragendorff's reagent. The presence of yellow-orange solution indicated the presence of alkaloid compounds.

\section{Flavonoid Compound}

Magnesium powder and hydrochloric acid was added into the extract. The mixture was then heated over a water bath, then filtered. The obtained filtrate was then added with amyl alcohol. The presence of orange, red or yellow solution indicated the presence of flavonoids.

\section{Polyphenol Compound}

The extract was heated over a water bath and then filtered. The obtained filtrate was added with iron (III) chloride solution. The presence of the black-blue-green solution indicated the presence of polyphenol compounds. 
Table 2. Antiproliferative activity of $C$. pallida Aiton

\begin{tabular}{|c|c|c|c|c|c|c|c|c|c|}
\hline \multirow{2}{*}{ Sample } & \multicolumn{8}{|c|}{ Concentration } & \multirow{2}{*}{$\mathrm{IC}_{50}(\mu \mathrm{g} / \mathrm{ml})$} \\
\hline & 8 & 16 & 31 & 63 & 125 & 250 & 500 & 1000 & \\
\hline Leaves (ethanol extract) & 0 & 8 & 33 & 54 & 86 & 85 & 84 & 80 & 56.7 \\
\hline N-hexane fraction & 0 & 6 & 27 & 44 & 53 & 77 & 86 & 84 & 107.1 \\
\hline Ethyl acetate fraction & 0 & 16 & 54 & 79 & 89 & 86 & 83 & 77 & 29.67 \\
\hline Destilled water fraction & 0 & 0 & 0 & 0 & 18 & 65 & 85 & 82 & $>200$ \\
\hline Seeds (ethanol extract) & 12 & 18 & 29 & 46 & 28 & 35 & 57 & 84 & $>200$ \\
\hline N-hexane fraction & 0 & 0 & 49 & 57 & 84 & 89 & 88 & 89 & 35.71 \\
\hline Ethyl acetate fraction & 1 & 22 & 40 & 65 & 52 & 68 & 86 & 88 & 44.25 \\
\hline Distilled water fraction & 0 & 0 & 0 & 0 & 0 & 0 & 0 & 0 & - \\
\hline
\end{tabular}

\section{Quinone Compound}

The extract was heated over a water bath and then filtered. Potassium hydroxide solution. $(5 \%)$ was added into the solution. The presence of quinone compounds was shown by the formation of yellow to red solution.

\section{Tanin Compound}

The extract was heated over a water bath and then filtered. Gelatin solution $(1 \%)$ was added into th extract. The presence of white sediment indicated the presence of tannin compound.

\section{Monoterpenoid and Sesquiterpenoid}

The extract was grinded and evaporated. Dried extract was then added with $10 \%$ vanillin solution in concentrated sulfuric acid solution. The color changes indicated the presence of monoterpenoid and sesquiterpenoid.

\section{Triterpenoid and Steroid}

The extract was added with ether solution. Approximately $0.5 \mathrm{ml}$ of anhydrous acetic acid, $0.5 \mathrm{ml}$ of chloroform, and $1 \mathrm{ml}$ of concentrated sulphuric acid were added into the solution. The formation of purplebrown ring on the second layer of the solution indicated the presence of steroid or triterpenoid.

\section{Saponin Compound}

The extract was heated over a water bath and then filtered. After the extract was cold, it was shaken rigorously for approximately 30 seconds. Hydrochloric acid. was then added into the foam to examine the presence of saponin compound.

Anti-proliferative test was performed using MTT assay. Various concentrations of extracts were put in a 96 well plate containing MCF-7 cells, and were then incubated for 24 hours. Ten $\mu$ L of WST- 8 solution was added to each well and incubated for 3 hours at $37^{\circ} \mathrm{C}$. The reaction was discontinued with the addition of SDS reagent $(100 \mu \mathrm{l})$. Cell proliferation rate was determined by reading the microtiter plate and measuring the absorbance at 450 nm.

\section{Results and Discussion}

Breast cancer is one of the most prevalent types of malignancy among woman in both developed and developing countries. ${ }^{8}$ Cancer 


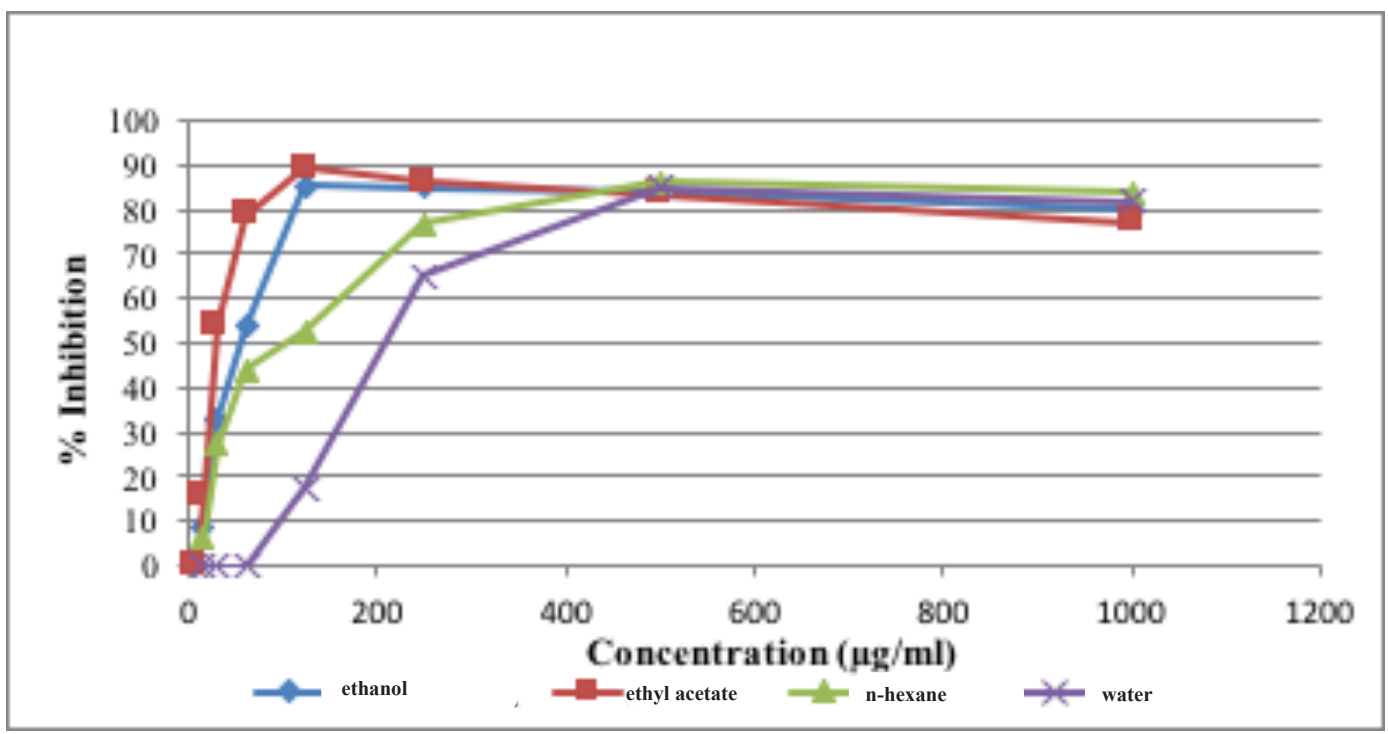

Figure 1. Anti-Proliferative Activity of $C$. Pallida Aiton Leaves

chemotherapy plays a vital role in this disease management. The main objective of such treatment is eliminate the cancer, without causing harm to the host cells. Researchers are predominantly interested in the treatment that are selective and can possibly induce cellular apoptosis, activity that is satisfied by several secondary metabolites of the plant. $^{9}$

The yields of concentrated extracts of $C$. pallida Aiton leaves and seeds were $57 \mathrm{~g}$ and $42 \mathrm{~g}$, respectively. In this study, ethanol was used since it is a universal solvent which attract polar, semi polar and non polar secondary metabolites. ${ }^{7}$ The results of phytochemical screening can be found in Table 1 .

The WST assay results showed that the extract and fraction of $C$. pallida Aiton had anti-proliferative activity. The lowest $\mathrm{IC}_{50}$ was observed in ethyl acetate leaves fraction $(29.67 \mu \mathrm{g} / \mathrm{ml})$ and $\mathrm{n}$-hexane seeds fraction (35.41 $\mu \mathrm{g} / \mathrm{ml})$ (Table 2).
The presence of several phytochemicals may contribute to its anti-cancer activities, such as alkaloid, flavonoid, and terpenoid. Previous studies showed that alkaloid might modulate microtubule activity. Microtubules contribute in the formation of mitotic spindle, making it becomes suitable target for anticancer drugs. Vinblastine is one type of the alkaloid compound which has been isolated for anti-cancer drug development. ${ }^{8-11}$

Flavonoids might also induce antiproliferative activity of $C$. pallida extract. Previous study showed that it might interferes with multiple mechanism, including signal transduction. Several flavonoid compounds could also activate apoptotic proteins and induce DNA damage in cancer cells. ${ }^{12}$

\section{Conclusion}

Ethyl acetate fraction of $C$. pallida Aiton is potential to be developed as anti cancer agent. 


\section{Acknowledgement}

None.

\section{Funding}

None.

\section{Conflict of Interest}

None declared.

\section{References}

1. Sharma GN, Dave R, Sanadya J, Sharma P, Sharma K. Various types and management of breast cancer. Journal of Advanced Pharmaceutical Technology \& Research. 2010;1:109.

2. Locke WJ, Clark SJ. Epigenome remodelling in breast cancer: insights from an early in vitro model of carcinogenesis. Breast Cancer Research. 2012;14:215.

3. Donepudi MS, Kondapalli K, Amos SJ, Venkanteshan P. Breast cancer statistics and markers. Journal of Cancer Research Therapy. 2014;10(3):506-511.

4. Desai AG, Qazi GN, Ganju RK, El-Tamer M, Singh J, Saxena AK. Medicinal plants and cancer chemoprevention. Current Drug Metabolism. 2008;9:581-591.

5. Levitsky DO, Dembitsky VM. Antibreast cancer agents derived from plants. Natural Product of Bioprospect. 2014;5:1-16.

6. Boldrin, PK, Resende, FA. Estrogenic and mutagenic activities of Crotalaria pallida measured by recombinant yeast assay and Ames test. BMC Complementary and Alternative Medicine.2013;13(1):216.

7. Khalighi-Sigaroodi F, Ahvazi M, Hadjiakhoondi A, Cytotoxicity and antioxidant activity of 23 plant species of Leguminoceae family. Iran Journal of Pharmaceutical Research. 2012;11(1):295-302.

8. Maioli MA, Alves LC, Perandin D.
Cytotoxicity of monocrotaline in isolated rat hepatocytes: effects of dithiothreitol and fructose. Toxicology. 2011;57(7);1057-1064.

9. Moudi M, Go R. Vinca alkaloids. International Journal of Preventive Medice. 2013;4(11):1231-1235.

10. Subarnas A, Diantini A, Abdulah R, Zuhrotun A. Apoptosis induced in MCF-7 human breast cancer cells by 2,4-dihydroxy-6-methoxy-3,5dimethylchalcone isolated from Eugenia aquea leaves. Oncology Letters. 2015;9(5):2303-2306.

11. Sakarkar DM, Deshmukh VN. Ethnopharmacological review of traditional medicinal plants for anticancer activity. International Journal of Pharmaceutical Technology Research. 2011;3:298-308.

12. Chahar MK, Sharma N, Dobhal MP, Joshi YC. Flavonoids: a versatile source of anticancer drugs. Pharmacognosy Review. 2011;5:1-12. 